\title{
Immunohistochemistry pattern of hepatic inflammatory and insulin resistance markers in experimental model of nonalcoholic steatohepatitis
}

\author{
Imunoexpressão hepática de marcadores inflamatórios e \\ de resistência insulínica na esteato-hepatite não alcóolica
}

Mônica Souza de Miranda Henriques'; Jacqueline Alves Leite²; Margareth de Fátima Formiga de Melo Diniz ${ }^{3}$; Maria Salete Trigueiro de Araújo

\begin{abstract}
Introduction: The pathophysiology of nonalcoholic steatohepatitis (NAS) includes, basically, insulin resistance, inflammation and oxidative stress. Thus, a study of immunostaining for liver insulin, adiponectin, tumor necrosis factor alpha (TNF- $\alpha$ ), and inducible nitric oxide synthase (iNOS) receptors was conducted. Objective: To expand the knowledge about the pathophysiological and molecular mechanisms underlying the experimental model of steatohepatitis in rats fed a high-fat diet. Method: Twenty Wistar rats were divided into two groups: G1 (control, fed a standard diet), and G2 (fed a high-fat diet containing 58\% of energy derived from fat, $18 \%$ from protein and 24\% from carbohydrate). After eight weeks the animals were sacrificed. Blood glucose, insulin, total cholesterol, high-density lipoprotein (HDL), the very low-density lipoproteins (VLDL), triglycerides, aspartate aminotransferase (AST), alanine aminotransferase (ALT), alkaline phosphatase (ALP) and gamma-glutamyl transferase (GGT) were determined. The liver tissue was submitted to histopathological analysis, using a NAS score. In immunohistochemistry, we studied the expression of the insulin receptor, adiponectin, TNF- $\alpha$ and iNOS by tissue microarray method. Results and conclusion: There was marked cytoplasmic immunostaining for TNF- $\alpha$ and iNOS mediators in the group on a fat diet. Regarding insulin and adiponectin molecular markers, a reduction of cytoplasmic immunoreactivity of these antigens was observed in the group on a fat diet, reflecting, respectively, the state of hepatocellular inflammation (steatohepatitis) and insulin resistance in this experimental model of fat liver disease.
\end{abstract}

Key words: nonalcoholic steatohepatitis; nitric oxide; adiponectin; TNF- $\alpha$; iNOS; immunohistochemistry.

\section{INTRODUCTION}

The non-alcoholic fatty liver disease (NAFLD) has a progressive morphological spectrum and two distinct presentation forms: the fatty liver disease (FLD), characterized solely by the deposit of fat in liver cells, and non alcoholic steatohepatitis (NASH), the most severe form of the disease, in which variable degrees of necrosis and inflammation are observed ${ }^{(19)}$. NAFLD pathogenic mechanisms remain under investigation; however, triglyceride accumulation in the interior of liver cells, resulting from insulin resistance, is considered the first step in the proposed and most accepted pathogenic model at the moment ${ }^{(6,19)}$. The oxidative stress resulting from mitochondrial oxidation of fatty acids and the expression of inflammatory cytokines have been pointed out as secondary causal factors, which lead to liver damage, fibrosis and inflammation ${ }^{(8)}$.

NAFLD diagnosis is based on histopathological findings associated with clinical laboratory data ${ }^{(10,12)}$, and steatosis is an

First submission on 18/09/13; last submission on 18/01/14; accepted for publication on 20/01/14; published on 20/02/14

1. PhD in Pharmaceutical Sciences; Professor of Internal Medicine Department at Universidade Federal da Paraíba (UFPB).

2. Doctoral student of Pharmaceutical Sciences at UFPB.

3.PhD in Pharmaceutical Sciences; professor of the Post Graduation Program in Bioactive Natural and Synthetic Products at UFPB.

4. PhD in Human Pathology from Université Claude Bernard Lyon I; researcher at the Laboratory of Animal Pathology of UFPB. 
indispensable element for diagnosis. Associated inflammation may be intermittent or have a secondary role in the progression to cirrhosis. The presence of ballooning is important, for it is a sign of cell membrane lipid peroxidation, with a resulting permeability disorder. The finding of Mallory bodies signals hyaline coagulation of hepatocyte cytoplasmic proteins. Perisinusoidal fibrosis is an important marker of chronicity, consequently reflecting the evolutive potential of the disease. It is a phenomenon that, in general, follows steatosis, ballooning and hepatocytolisis; it may be interpreted as a consequence of liver injury, and it is not indispensable for diagnosis ${ }^{(3)}$. The early phases of NASH, generally with no fibrosis, represent the moment when diagnostic and therapeutic strategies must be employed to avoid the progression to chronic forms.

Immunohistochemistry is a method for detecting cellular tissue antigens, using antigen-antibody reactions, by means of optical microscopy. This process has various applications: histogenesis, sub-typing, and diagnosis of neoplasms; study of inflammatory and infectious diseases; determination of the oncogenic potential, with key importance in the determination of predictive and prognostic factors in cancer ${ }^{(31)}$, including the hepatic cancer ${ }^{(32)}$.

Great developments have been made in the comprehension of NAFLD, but little is known about the underlying mechanisms of progression from steatosis to steatohepatitis. Immunohistochemistry is a possible additional resource used in clinical and experimental researches about NAFLD, in which several types of antibodies may be used to study steatosis, inflammation, adhesion molecules, fibrosis, and others.

\section{OBJECTIVES}

Based upon insulin resistance, inflammation and oxidative stress, we chose to conduct an experimental study about the immunohistochemistry pattern of liver insulin receptors, adiponectin, tumor necrosis factor alpha (TNF- $\alpha$ ), and inducible nitric oxide synthase (iNOS), aiming at expanding knowledge about molecular mechanisms underlying the experimental model of steatohepatitis in rats fed a high-fat diet.

\section{METHOD}

The study was approved by the animal research ethics committee of the Laboratory of Pharmaceutical Technology of Universidade Federal da Paraiba (UFPB) and carried out according to the guidelines for animal experimentation. Twenty 2-month-old Winstar rats, with $250 \mathrm{~g}$ to $300 \mathrm{~g}$ in weight, originating from Professor Thomas George Bioterium, were used in the experiment. The animals were kept in polyethylene cages (five animals per cage) at constant temperature and humidity conditions, with free access to food and water, and alternate cycles of 12 hours light and darkness. Weight was recorded once a week. They were divided into two groups: G1 (normal control, fed a standard diet); G2 (control group, fed a high-fat diet containing $58 \%$ of energy derived from fat, $18 \%$ from proteins, and $24 \%$ from carbohydrates). After eight weeks, the animals were killed, after an eight-hour fast. Glycemia, total cholesterol and fractions, and triglycerides were determined through enzymatic methods; insulinemia, by radioimmunoassay. The exams related to hepatic assessment included the determination of serum levels of aspartate aminotransferase (AST), alanine aminotransferase (ALT), alkaline phosphatase (ALP) and gamma-glutamyl transferase (GGT), by a kinetic method ${ }^{(9)}$.

The technical procedures for histological analysis of liver included, in succession, the steps previously described ${ }^{(22)}$. For the immunohistochemical study, the tissue microarray $\left(\right.$ TMA ${ }^{(4,}{ }^{(20)}$ technique was used. The adopted protocol for immunohistochemical exam was adapted to local laboratory conditions $^{(29)}$

The careful selection for biopsies, including the most representative areas of histological alterations of paraffinembedded liver, aimed at minimizing the effects of heterogeneity of liver lesions.

Slides were submitted to immunohistochemistry for incubation with antibodies against adiponectin, insulin receptor, TNF- $\alpha$ and iNOS, using a 1:200 dilution. Processing took place on the BenchMark ${ }^{\circledR}$ XT Slide Staining System of Ventana Medical Systems (Arizona, USA). Previously, standardization of the immunostaining technique was performed, to determine the optimal antibody concentration. The mentioned apparatus propitiated better a dilution technique, antigenic recovery, antibody incubation, amplification and reaction development, by the chromogenic substance diaminobenzidine (DAB).

TMA construction and the immunohistochemical techniques were performed at the Pathology Department of Hospital do Câncer A.C. Camargo (São Paulo-SP) (Table 1 and 2).

\section{Statistical analysis}

The used statistical techniques were analysis of variance (ANOVA), for one and two factors, including the Tukey multiple 
TABLE 1 - Used antibodies and reaction protocols

\begin{tabular}{cccccc}
\hline Antibody & Trademark & Clone & Dilution & $\begin{array}{c}\text { Antigenic } \\
\text { recovery } \\
\text { solution }\end{array}$ & $\begin{array}{c}\text { Amplification } \\
\text { system }\end{array}$ \\
\hline Adiponectin & ABCAM & Polyclonal & $1 / 200$ & $\begin{array}{c}\text { Citrate } \\
\text { pH6.0 }\end{array}$ & NLMPN \\
$\begin{array}{c}\text { Insulin } \\
\text { receptor }\end{array}$ & ABCAM & Polyclonal & $1 / 200$ & $\begin{array}{c}\text { Citrate } \\
\text { pH6.0 }\end{array}$ & NLMPN \\
TNF- $\alpha$ & ABCAM & Polyclonal & $1 / 200$ & $\begin{array}{c}\text { Citrate } \\
\text { pH6.0 }\end{array}$ & NLMPN \\
iNOS & ABCAM & Polyclonal & $1 / 200$ & $\begin{array}{c}\text { Citrate } \\
\text { pH6.0 }\end{array}$ & NLMPN \\
\hline
\end{tabular}

NLMPN: Novolink Max Polymer-Novocasta.

TABLE 2 - Immunoreaction scoring, according to the number of stained cells, for semi-quantitative analysis of slides

\begin{tabular}{cc}
\hline Quantification & Grade \\
\hline No positive cell & 0 \\
$<10 \%$ of positive cells & 1 \\
$10 \%-50 \%$ of positive cells & 2 \\
$51 \%-90 \%$ of positive cells & 3 \\
$>90 \%$ of positive cells & 4 \\
\hline
\end{tabular}

comparisons tests; Dwass-Steel-Chritchlow-Fligner test; and the non-parametric Kruskal-Wallis test. All tests were analyzed at the $5 \%$ significance level $(p<0.05)$. The used softwares in the analysis were Stata version 9.0, SPSS for Windows (Statistical Package for the Social Sciences) version 18.0 and Statistical Data Analysis R - statistical computing and graphics, version 2.13.1 (2011-07-08) and Software MYSTAT - Statistical Analysis Product - version 12.0 .

\section{RESULTS}

TABLE 3 - Descriptive measures of percentage values of positivity and of the respective tests $\mathrm{F}$ (Anova), found for adiponectin, insulin receptor, TNF- $\alpha$ and iNOS, in the control group (G1) and in the group on the high-fat diet (G2)

\begin{tabular}{cccccc}
\hline & \multicolumn{2}{c}{$\begin{array}{c}\text { Groups } \\
\text { Mean (\%) }\end{array}$} & $\begin{array}{c}\text { Standard } \\
\text { error }\end{array}$ & $\begin{array}{c}\text { 95\% confidence } \\
\text { interval }\end{array}$ \\
\hline \multirow{2}{*}{ Adiponectin } & G1 & 95.30 & 1.274 & 92.42 & 98.18 \\
& G2 & 7 & 0.615 & 5.61 & 8.39 \\
Insulin & G1 & 96.3 & 1.202 & 93.58 & 99,02 \\
receptor & G2 & 48.7 & 2.087 & 43.98 & 53.42 \\
& G1 & 8.8 & 0.327 & 8.06 & 9.54 \\
TNF- $\alpha$ & G2 & 94.6 & 1.72 & 90.71 & 98.49 \\
& G1 & 8.4 & 0.4 & 7.5 & 9.3 \\
iNOS & G2 & 94.1 & 1.574 & 90.54 & 97.66 \\
\hline
\end{tabular}

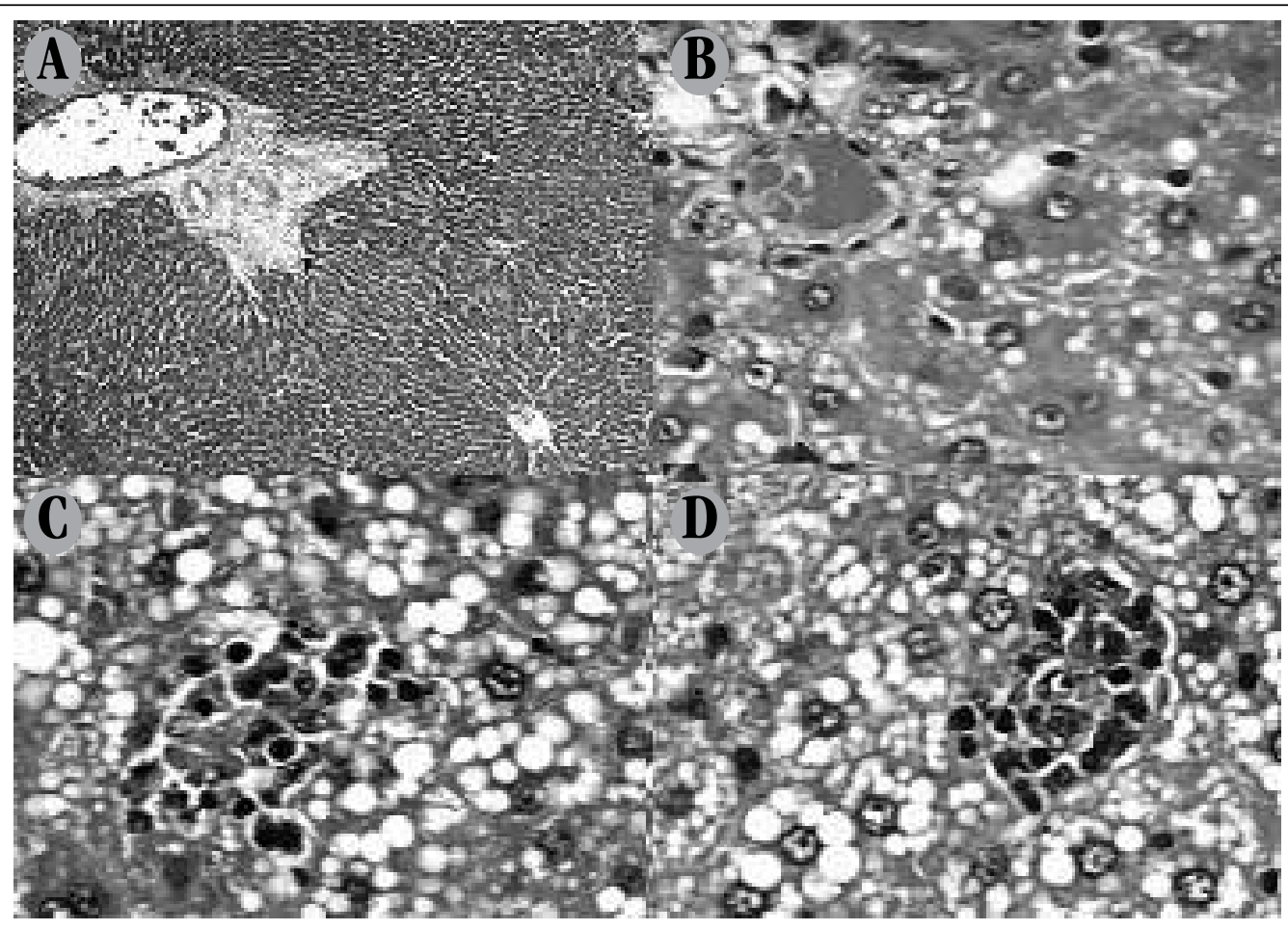

FIGURE 1 -Isomorphic hepatocytes, trabeculation, portal space with no fibrous expansion, absence of portal and periportal inflammation in hepatic specimen of the control group A) presence of moderate microvesicular steatosis in 1, in hepatic specimen of animal on high-fat diet; B) severe macrovesicular steatosis associated with mixture inflammatory infiltrate in 2 , in hepatic specimen of animal on high-fat diet; $C$ ) presence of microgranuloma in hepatic specimen of animal on bigh-fat diet; $D$ ) bematoxylin and eosin $40 \times$; $B-D$ : bematoxylin and eosin 100x. 
TABLE 4 - Descriptive values of biochemical parameters in the control group and the group on high-fat diet

\begin{tabular}{cccc}
\hline \multirow{2}{*}{ Variables } & \multicolumn{2}{c}{ Mean \pm standard error } & \multirow{2}{*}{ G value } \\
\cline { 2 - 3 } & G1 & G2 & \\
\hline Glycemia & $95.6 \pm 28.7$ & $233.6 \pm 40.7$ & $<0.001$ \\
Insulin & $1.68 \pm 0.07$ & $3.54 \pm 0.08$ & 0.001 \\
HOMA-IR & $0.42 \pm 0.05$ & $2.01 \pm 0.09$ & 0.001 \\
Cholesterol & $41.33 \pm 8.1$ & $53.2 \pm 6.2$ & $<0.001$ \\
HDL & $18.8 \pm 3.3$ & $15.8 \pm 2.3$ & 0.01 \\
VLDL & $7.1 \pm 21.6$ & $22.3 \pm 3.5$ & $<0.001$ \\
TG & $35.6 \pm 23.2$ & $111.6 \pm 18.9$ & $<0.001$ \\
ALP & $165 \pm 44.1$ & $180.1 \pm 58.6$ & $<0.001$ \\
GGT & $2.7 \pm 0.7$ & $2.3 \pm 1.1$ & $<0.001$ \\
ALT & $169.8 \pm 62.6$ & $271.5 \pm 108.2$ & $<0.001$ \\
AST & $49.1 \pm 17.6$ & $84.7 \pm 101.1$ & 0.01 \\
\hline
\end{tabular}

G1: normal control; G2: high-fat diet; results of test $H$ of Kruskal-Waills of the differences among Xroups according to variables that compose the biochemical exams.

HOMA-IR: homeostatic model assessment of insulin resistance; HDL: high-density lipoprotein; VLDL: very low-density lipoproteins; TG: triglycerides; ALP: alkaline phosphatase; GGT: gamma-glutamyl transferase; ALT: alanine aminotransferase; AST: aspartate aminotransferase.
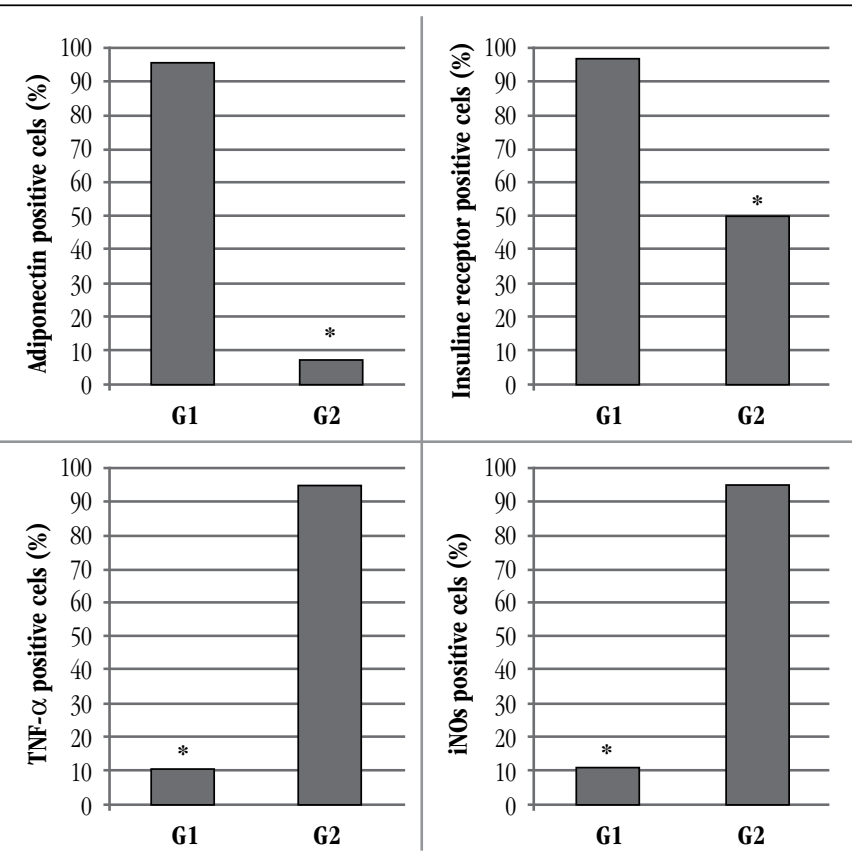

FIGURE 2 - Positivity for immunoexpression of adiponectin, insulin receptor, TNF- $\alpha$ and iNOS in control group (G1) and group on the high-fat diet (G2)

TNF- $\alpha$ : tumor necrosis factor alpha; iNOS: inducible nitric oxide synthase.

*Statistically significant difference.
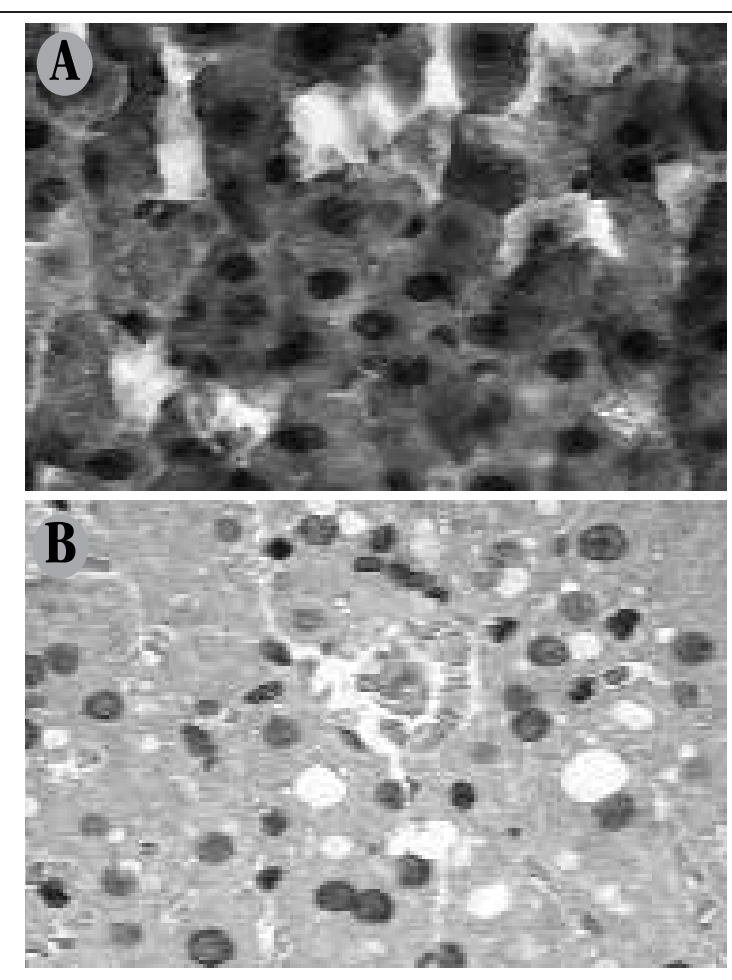

FIGURE 3 - Pattern of cytoplasmic immunostaining for liver adiponectin A) strong and diffuse in animals of the control group $(400 \times)$; B) low positivity in the bigh-fat diet associated to steatosis areas $(400 \times)$.
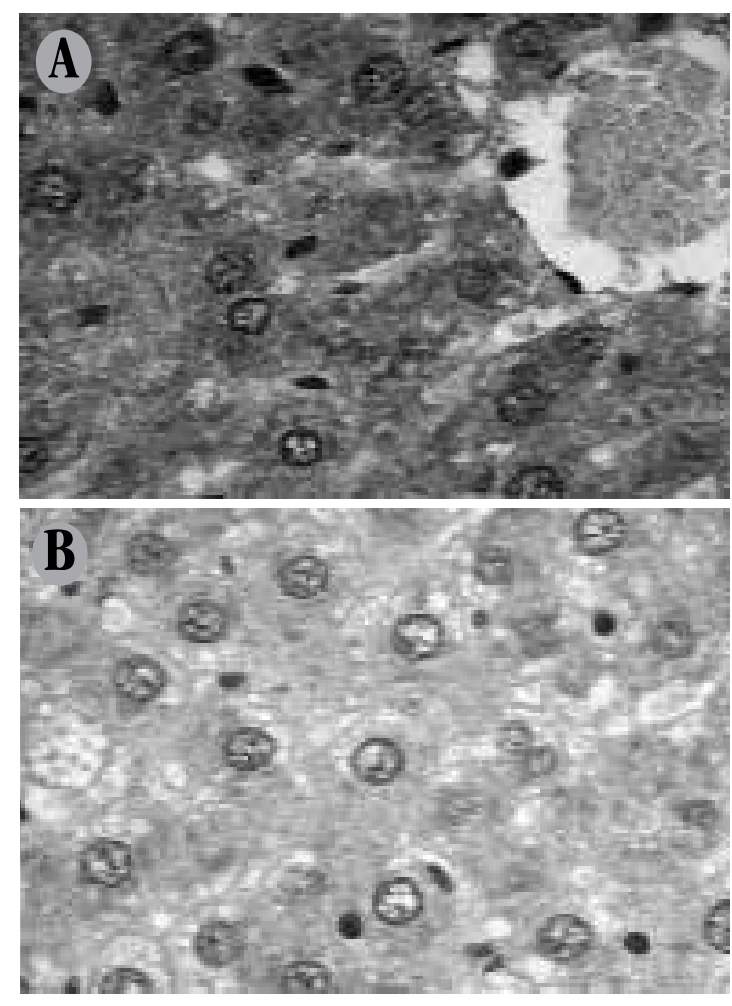

FIGURE 4 - Pattern of cytoplasmic immunostaining for liver insulin recepto A) animals of the control group $(400 \times)$; B) high-fat diet $(400 \times)$. 

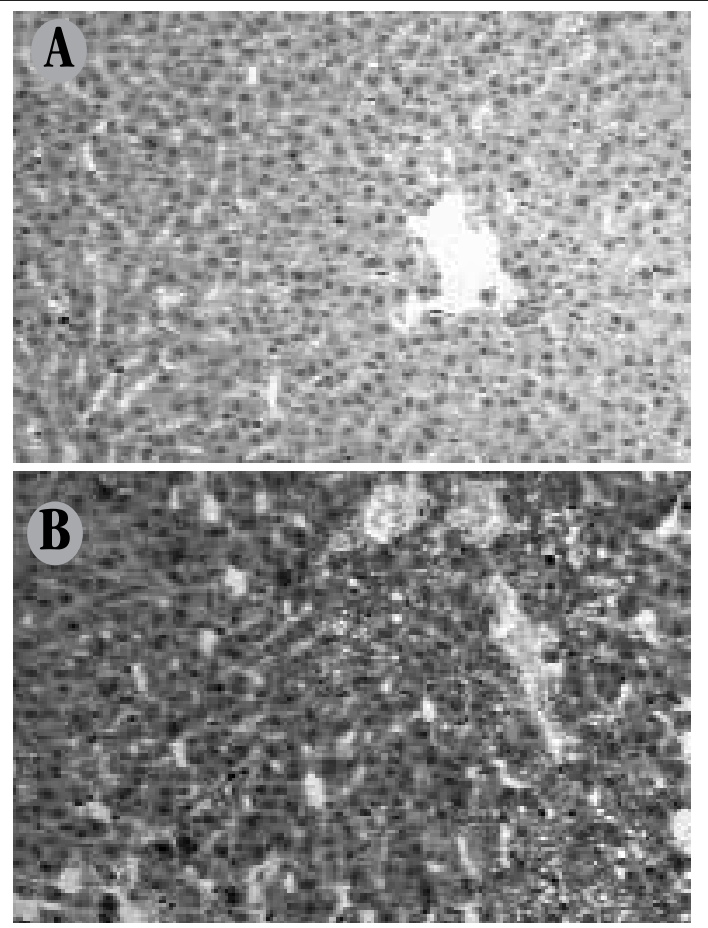

FIGURE 5 - Pattern of cytoplasmic immunostaining for liver TNF- $\alpha$ A) in the control group $(25 \times) ; B)$ intense and diffuse cell staining associated to steatosis in the group on the high-fat diet (25x).

TNF- $\alpha$ : tumor necrosis factor alpha.
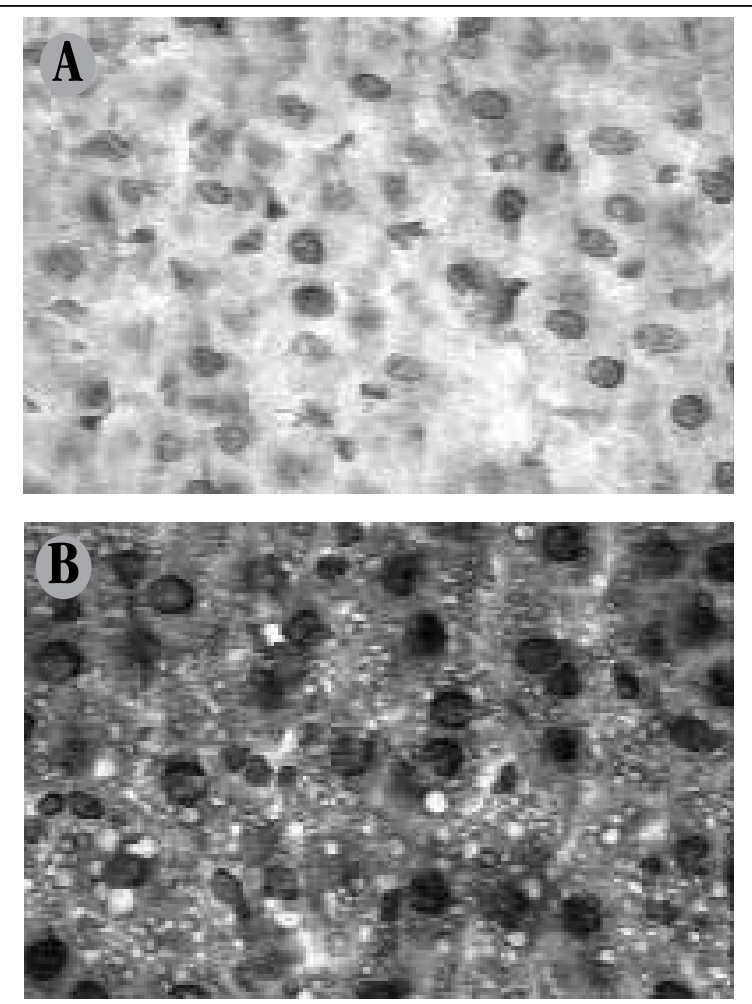

FIGURE $\mathbf{6}$ - Pattern of cytoplasmic immunostaining for liver iNOs

A) in the control group with scarce cytoplasmic staining (400×); B) intense and diffuse reaction associated to steatosis in the group on the high-fat diet (400×). iNOS: inducible nitric oxide synthase.

\section{DISCUSSION}

In this work, the immunostaining pattern for adiponectin, insulin receptor, TNF- $\alpha$ and iNOs was studied in hepatic tissue samples of Winstar rats fed a high-fat diet compared with the control group.

The model of immunohistochemical expression of adiponectin, TNF- $\alpha$, insulin receptor, and iNOs, in the current research, represented a way to identify pathogenic mechanisms and possible therapeutic interventions directed against these molecular targets.

The role of immunohistochemical analysis in the diagnosis and management of NASH has been discussed ${ }^{(30)}$. Authors defend the use of molecular methods in clinical practice to perform differential diagnosis; and, in research, to study biological targets for novel therapies ${ }^{(17,30)}$.

Oxidative stress is one of the responsible for the production of proinflammatory cytokines, among which TNF- $\alpha$, transforming growth factors alpha (TGF- $\alpha$ ) and beta (TGF- $\beta$ ), interleukins 6 (IL-6) and 8 (IL-8), nuclear factor-kappa B (NFKB) and adiponectin stand out. These cytokines are produced by lymphocytes and Kupffer cells, through free radical-mediated mechanisms, by altering mitochondrial membrane permeability and inhibiting the respiratory chain ${ }^{(2,5,16,24)}$.

Adiponectin is the most abundant adipocytokine, exclusively synthesized in adipose tissue ${ }^{(5)}$. It stimulates the release of antiinflammatory cytokines, such as IL-10, for instance, which blocks NFKB activation and inhibits TNF- $\alpha$ production, and IL- $6^{(5,33)}$. In the liver, it stimulates mitogen-activated protein kinase (MAPK), peroxisome proliferator-activated receptor alpha (PPAR- $\alpha$ ), and inhibits toll-like receptor 4 (TLR- 4 ) signaling. There is evidence that adiponectin decreases hepatic and systematic insulin resistance, attenuates necroinflammation and hepatic fibrosis. Decreased adiponectin synthesis indicates the severity of $\operatorname{NAFLD}^{(13,21,27,28)}$

Drugs that increase adiponectin levels may be considered therapeutic targets for the treatment of NAFLD. The identification of molecules involved in adiponectin signaling pathways and the potential role of its receptors resistance in NASH have been little investigated and seem promising in the treatment of NAFLD ${ }^{(5)}$.

TNF- $\alpha$ is produced by B- and T-lymphocytes (natural killer), macrophages and fibroblasts, and plays a key role in the evolution of NAFLD to NASH ${ }^{(16)}$. Synthesized in its inactive form, this cytokine becomes toxic in the tissue, inducing necrosis and angiogenesis. In low concentrations, TNF- $\alpha$ stimulates cell growth. On the 
other hand, in high concentrations, it suppresses cell development induced by other factors, whose high levels are associated with obesity and insulin resistance in animal and human models ${ }^{(21)}$. This cytokine produces lipogenic and fibrogenic effects, mediated by a paracrine mechanism that involves activation of Kupfer cells with release of soluble mediators, which stimulate the transformation of Ito cells into myofibroblasts, which, in its turn, start to synthesize components of extracellular matrix.

Among the three forms of nitric oxide (NO) synthase, iNOS is the most strongly associated with the inflammatory mediators involved in insulin resistance ${ }^{(13)}$. NO potentiates cytotoxicity caused by oxidative stress, through the reaction between superoxide anion and the formation of nitrotyrosine, whose intrahepatic accumulation is associated with the severity of steatohepatitis, what strongly suggests that oxidative stress plays a role in the pathogenesis of this disease. Studies in obese mice have demonstrated that, in severe steatosis, liver injury is mediated by TNF- $\alpha$ and Interferon- $\gamma$ (IFN- $\gamma$ ). This demonstrates that inflammatory cytokines are directly involved in the iNOSmediated upregulation. The expression of receptors for iNOS, by means of histochemistry, proved strongly positive in hepatocytes of mice on high-fat diet ${ }^{(14)}$.

At the hepatic vasculature, insulin resistance may be detected earlier than inflammation or any other sign of NAFLD. The administration of a high-fat diet induces insulin resistance in the liver sinusoidal endothelium, which is mediated, at least partially, through iNOS upregulation ${ }^{(25)}$.

Current evidence has highlighted the importance of $\mathrm{NO}$ as a therapeutic target, for its participation in glycemic and lipemic metabolic control, besides the already known actions on neuronal transmission, vascular relaxation, immune modulation and cytotoxicity. The inhibition of NO synthase reduced adiposity and improved insulin resistance in an experimental obesity model of rats fed on a high-fat $\operatorname{diet}^{(34)}$. The blockage of N0 synthase by $\mathrm{N}(\mathrm{G})$-nitro-L-arginine methyl ester (L-NAME) reduced glycerol release in human adipocytes ${ }^{(1)}$. In rat myocytes it stimulated glucose transport ${ }^{(18)}$ and stimulated glucose uptake in the skeletal muscle $^{(15)}$.

Among NO synthase isoforms, the inducible has been associated with responses to a variety of inflammatory stimuli, like those produced by proinflammatory cytokines and bacterial endotoxins. The iNOS modulates the release of great amounts of NO, and it may contribute to the development of obesity-related glucose intolerance ${ }^{(7,14)}$. A key role for iNOS in the pathogenesis of obesity-linked insulin resistance, has been supported by observations that targeted disruption iNOS protects against muscle insulin resistance and improves systematic insulin action in obese rats ${ }^{(26)}$. More recently, iNOS inhibition in mice also protected against the adverse effects associated with the high level of fat in states of insulin resistance ${ }^{(23)}$ and in genetically determined obesity models ${ }^{(13)}$. Besides, this enzyme was induced in the skeletal muscle and adipose tissue of type 2 diabetic patients ${ }^{(11,35)}$, whose expression correlated with the occurrence of insulin resistance ${ }^{(35)}$ and obesity ${ }^{(11)}$.

\section{CONCLUSION}

The results of the immunohistochemical investigation using the TMA technique revealed marked cytoplasmic immunostaining for the mediators TNF- $\alpha$ and iNOS in the group on the high-fat diet. As regards insulin and adiponectin, reduced cytoplasmic immunostaining of these antigens was observed in the group on the high-fat diet, reflecting, respectively, the state of insulin resistance and steatohepatitis developed in this group of animals.

\section{ACKNOWLEDGEMENTS}

The authors are grateful to Professor Fernando Augusto Soares, head of the Anatomic Pathology Department at Hospital A.C. Camargo, for the invaluable help with the conduction of the immunohistochemistry assays.

\section{RESUMO}

Introdução: Os mecanismos fisiopatológicos da esteato-hepatite não alcoólica incluem basicamente resistência insulinica, processo inflamatório e estresse oxidativo. Desta forma, um estudo sobre o padrão de imunoexpressão hepática para receptores de insulina, adiponectina, fator de necrose tumoral alfa (TNF- $\alpha$ ) e sintase indutivel do óxido nitrico (iNOS) foi conduzido. Objetivo: Ampliar os conhecimentos sobre os mecanismos moleculares subjacentes, em modelo experimental de esteato-hepatite. Método: Vinte ratos Wistar com dois meses de idade, pesando de 250 a $300 \mathrm{mg}$ foram subdivididos em dois grupos: G1 (controle normal, submetido à dieta padrão) e G2 (grupo-controle, submetido à dieta biperlipídica contendo 58\% de energia derivada de gorduras, 18\% de 
proteinas e 24\% de carboidratos). Após oito semanas, os animais foram sacrificados; o sangue, submetido à análise bioquimica; e o fígado, removido e fixado em formalina tamponada e emblocado em parafina para estudo histopatológico. Para estudo imuno-bistoquímico, foi utilizada a técnica de microarranjo de tecido. As lâminas obtidas foram submetidas à incubação com os anticorpos contra adiponectina, receptor de insulina, TNF- $\alpha$ e iNOS. Resultados e conclusão: Observou-se marcada imunoexpressão citoplasmática para os mediadores TNF- $\alpha$ e iNOS no grupo submetido à dieta biperlipidica. No que diz respeito aos marcadores moleculares insulina e adiponectina, observou-se uma redução da imunoexpressão citoplasmática desses anticorpos no grupo submetido à dieta hiperlipídica, traduzindo, respectivamente, o estado de inflamação hepatocelular (esteato-hepatite) e resistência insulinica, desenvolvidos nesse modelo experimental de doença hepática gordurosa.

Unitermos: esteato-hepatite não alcoólica; óxido nítrico; adiponectina; TNF- $\alpha$; iNOS; imuno-histoquímica.

\section{REFERENCES}

1. ANDERSSON, K. et al. A nitric oxide-mediated mechanism regulates lipolysis in human adipose tissue in vivo. Br J Pharmacol, v. 126, n. 7, p. 1639-45, 1999 .

2. BRAUNERSREUTHER, V. et al. Role of cytokines and chemokines in non-alcoholic fatty liver disease. World J Gastroenterol, v. 18, n. 8, p. 727-35, 2012.

3. BRUNT, E. M. Nonalcoholic fatty liver disease: what the pathologist can tell the clinician. Dig Dis, v. 30, n.1, p. 61-8, 2012.

4. BUBENDORF, L. et al. Tissue microarray (TMA) technology: miniaturized pathology archives for high-throughput in situ studies. J Pathol, v. 195, n. 1, p. 72-9, 2001.

5. BUECHLER, C.; WANNINGER, J.; NEUMEIER, M. Adiponectin, a key adipokine in obesity-related liver diseases. World J Gastroenterol, v. 17, n. 23, p. 2801-11, 2011.

6. COHEN, J. C.; HORTON, J. D.; HOBBS, H. H. Human fatty liver disease: old questions and new insights. Science, v. 332, n. 6037, p. 1519-23, 2011.

7. DALLAIRE, P. et al. Obese mice lacking inducible nitric oxide synthase are sensitized to the metabolic actions of peroxisome proliferatoractivated receptor-gamma agonism. Diabetes, v. 57, n. 8, p. 1999-2011, 2008.

8. DAY, C. P.; JAMES, 0. F. Steatohepatitis: a tale of two hits? Gastroenterology, v. 114, n. 4, p. 842-45, 1998.

9. DINIZ, M. F. F. M. Ensaios toxicológicos pré-clínicos com folhas da Cisampelos sympodialis Eichl (menispermaceae). João Pessoa, 2000. Tese (doutoramento) - Centro de Ciências da Saúde/Laboratório de Tecnologia Farmacêutica, Universidade Federal da Paraỉba, 2000.

10. DOWMAN, J. K.; TOMLINSON, J. W.; NEWSOME, P. N. Systematic review: the diagnosis and staging of non-alcoholic fatty liver disease and non-alcoholic steatohepatitis. Aliment Pharmacol Ther, v. 33, n. 5 , p. 525-40, 2011

11. ENGELI, S. et al. Regulation of the nitric oxide system in human adipose tissue.J Lipid Res, v. 45, n. 9, p. 1640-8, 2004.

12. FESTI, D. et al. Review article: the diagnosis of non-alcoholic fatty liver disease - availability and accuracy of non-invasive methods. Aliment Pharmacol Ther, v. 37, n. 4, p. 392-400, 2013.
13. FUJIMOTO, M. et al. A role for iNOS in fasting hyperglycemia and impaired insulin signaling in the liver of obese diabetic mice. Diabetes, v. 54 , n. 5 , p. $1340-8,2005$.

14. HA, S. K.; CHAE, C. Inducible nitric oxide distribution in the fatty liver of a mouse with high fat diet-induced obesity. Exp Anim, v. 59, n. 5 , p. 595-604, 2010.

15. HIGAKI, Y. et al. Nitric oxide increases glucose uptake through a mechanism that is distinct from the insulin and contraction pathways in rat skeletal muscle. Diabetes, v. 50, n. 2, p. 241-7, 2001.

16. HIJONA, E. et al. Inflammatory mediators of hepatic steatosis. Mediators Inflamm, v. 2010, Article 837419, 2010.

17. KANG, H. S. et al. Nuclear orphan receptor TAK1/TR4-deficient mice are protected against obesity-linked inflammation, hepatic steatosis, and insulin resistance. Diabetes, v. 60, n. 1, p. 177-88, 2011.

18. KAPUR, S. Expression of nitric oxide synthase in skeletal muscle: a novel role for nitric oxide as a modulator of insulin action. Diabetes, v. 46, n. 11, p. 1691-700, 1997.

19. KAWANO, Y.; COHEN, D. E. Mechanisms of hepatic triglyceride accumulation in non-alcoholic fatty liver disease.J Gastroenterol, v. 48, n. 4, p. 434-41, 2013.

20. KONONEN, J.et al. Tissue microarrays for high-throughput molecular profiling of tumor specimens. Nat Med, v. 4, n. 7, p. 844-7, 1998.

21. MASAKI, T. et al. Adiponectin protects LPS-induced liver injury through modulation of TNF-alpha in KK-Ay obese mice. Hepatology, v. 40, n. 1, p. 177-84, 2004.

22. MICHALANY, J. Técnica bistológica em anatomia patológica: com instruções para o cirurgião, enfermeira e citotécnico. 3. ed. São Paulo: Michalany, 1998, p. 295.

23. NORONHA, B. T. et al. Inducible nitric oxide synthase has divergent effects on vascular and metabolic function in obesity. Diabetes, v. 54 , n. 4, p. 1082-9, 2005.

24. PAROLA, M.; MARRA, F. Adipokines and redox signaling: impact on fatty liver disease.Antioxid Redox Signal, v. 15, n. 2, p. 461-87, 2011.

25. PASARÍN, M. et al. Insulin resistance and liver microcirculation in a rat model of early NAFLD.J Hepatol, v. 55, n. 5, p. 1095-102, 2011.

26. PERREAUlT, M.; MARETTE, A. Targeted disruption of inducible nitric oxide synthase protects against obesity-linked insulin resistance in muscle. Nat Med, v. 7, n. 10, p. 1138-43, 2001. 
27. POLYZOS, S. A. et al. The role of adiponectin in the pathogenesis and treatment of non-alcoholic fatty liver disease. Diabetes Obes Metab, v. 12, n. 5 , p. 365-83, 2010.

28. POLYZOS, S. A. et al. Serum total adiponectin in nonalcoholic fatty liver disease: a systematic review and meta-analysis. Metabolism,v. 60 , n. 3, p. 313-26, 2011.

29. SANTOS, R. T. M. et al. Procedimentos laboratoriais em imunoistoquímica e hibridização "in situ". In: ALVES, V. A. F. et al. Editores. Manual de Imunoistoquímica. São Paulo: Sociedade Brasileira de Patologia,1999. p. 237-59.

30. SNOVER, D. Immuno-histochemical analysis in steatohepatitis. Does it have a role in diagnosis and management? Am J Clin Pathol, v.123, n. 4, p. 491-3, 2005.

31. STIEPCICH, M. M. A. Perfil de citoceratinas e sua relação com diferenciação e fatores clínico-morfológicos em carcinomas ductais
SOE de mama estudados em "array de tecido" (tissue microarray - TMA). São Paulo, 2007. Tese (doutoramento) - Fundação Antônio Prudente, 2007.

31. SU, J. S. et al. Clinicopathological characteristics in the differential diagnosis of hepatoid adenocarcinoma: a literature review. World J Gastroenterol, v. 19, n. 3, p. 321-7, 2013.

32. TILG, H.; MOSCHEN, A. R. Adipocytokines: mediators linking adipose tissue, inflammation and immunity. Nat Rev Immunol, v. 6, n. 10, p. 772-83, 2006.

33. TSUCHIYA, K.; et al. Chronic blockade of nitric oxide synthesis reduces adiposity and improves insulin resistance in high fat-induced obese mice. Endocrinology, v. 148, n. 10, p. 4548-56, 2007.

34. TORRES, S. H. et al. Inflammation and nitric oxide production in skeletal muscle of type 2 diabetic patients. J Endocrinol, v. 181, n. 3 , p. 419-27, 2004.

\section{MAILING ADDRESS}

